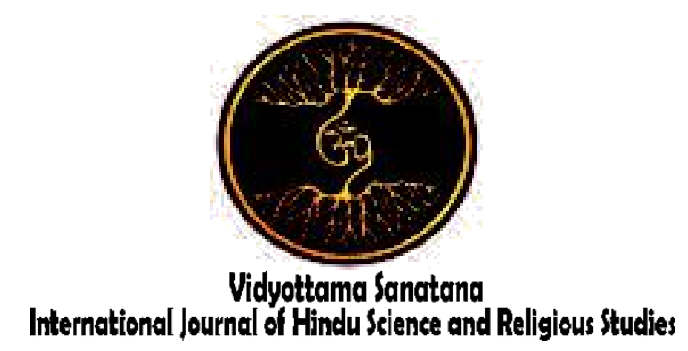

Vol. 4 No. 1 May 2020

\title{
IMPLEMENTATION OF HINDU RELIGIOUS EDUCATION CURRICULUM IN PASRAMAN RSI MARKANDEYA TARO, GIANYAR DISTRICT
}

\author{
By: \\ Ni Komang Sutriyanti ${ }^{1}$, I Made Dharmawan ${ }^{2}$ \\ ${ }^{12}$ Universitas Hindu Negeri I Gusti Bagus Sugriwa Denpasar \\ E-mail : ${ }^{1}$ nikomangsutriyanti@gmail.com, ${ }^{2}$ imadedharmawan6@gmail.com
}

\begin{tabular}{|l|l|l|}
\hline Received: December 17, 2019 & Accepted: May 12, 2020 & Published: May 30, 2020 \\
\hline
\end{tabular}

\begin{abstract}
The purpose of this study is to find out (1) Implementation of Hindu Religious Education Curriculum in PasramanRsiMarkandya Taro, Gianyar Regency, (2) The constraints faced in the Implementation of Hindu Religious Education Curriculum in Pasraman Rsi Markandya Taro, Gianyar Regency and (3) Efforts that undertaken to overcome the obstacles encountered in the Implementation of the Hindu Religious Education Curriculum in Pasraman Rsi Markandya Taro, Gianyar Regency. The theories that used in this research to answer the problem formulation are modern management theory, constructivism theory and excitement theory. This research is descriptive research with qualitative approach which is related to the implementation of the Hindu religious education curriculum in Pasraman Rsi Markandya Taro. The techniques of data collection used are: observation, interviews, study of literature and documentation. The data analysis technique used in this research is descriptive qualitative techniques, the Miles and Huberman cycle analysis models. The results of the research showed that: First, the implementation of Hindu religious education in Pasraman Rsi Markandeya Taro, Gianyar District had not been running optimally and there were still a lot of constraints, so it was necessary to conduct evaluations and follow up actions as well as acceleration of the expansion of facilities and infrastructure. Second, the constraints faced are human resources, time allocation, funding and facilities and infrastructure. Third, the efforts were done to solve the constraints encountered, namely providing training to teachers, developing learning programs and utilizing effective learning resources.
\end{abstract}

Keywords: Implementation, Curriculum, Pasraman 


\section{INTRODUCTION}

The success of an education is largely determined by many factors, several factors that can support that success such as the quality of human resources (HR), supporting facilities and infrastructure, as well as the accuracy of the curriculum used. Education must be able to adjust the dynamics that develop in society, especially the demands and needs of society and this can be answered by curriculum changes. In order to fulfill educational goals, the role of the curriculum in formal education is very strategic. So far there has been no harmony in the application of religious education, especially Hinduism in schools (Sandika, 2011). The Hindu religious education curriculum has a central position in the entire educational process. The Hindu religious curriculum directs all forms of educational activities and the achievement of educational goals.

In connection with the administration of education, Regulation of the Minister of Religion of the Republic of Indonesia Number 56 of 2014 concerning Hindu Religious Education in which managing Hindu formal and non-formal education channels in pasramanthat certainly requires guidance in management of education both in terms of planning, organizing, implementing and monitoring. Pasraman Rsi Markandya Taro is a formal pasraman that managing Hindu religious education institutions from kindergarten, elementary and junior high schools named Pratama Widya Pasraman, Adi Widya Pasraman and Madyama Widya Pasraman.

The administration of education naturally experiences both internal and external constraints. These constraints must certainly be sought for solutions to obtain educational results that are in accordance with the mandate of the Act and have implications for related aspects. Based on the phenomenon mentioned above, researchers are interested in further studying the implementation of Hindu religious education curriculum with the title "Implementation of Hindu Religious Education Curriculum in Pasraman Rsi Markandya Taro, Gianyar Regency". It is expected that the results of this study can be useful for the Directorate General of Hindu Community Guidance of the Indonesian Ministry of Religion as an evaluation material in the implementation of Hindu religious education in formal pasraman.

\section{METHOD}

The type of research used in this study is type of descriptive research with qualitative approach which is related to the implementation of the Hindu religious education curriculum in Pasraman Rsi Markandya Taro. The theories used in this research to answer the problem formulation are modern management theory, constructivism theory and (3) excitement theory. Data collection techniques used are: observation, interviews, study of literature and documentation. The data analysis technique used is descriptive qualitative techniques and Miles and Huberman cycle analysis models.

\section{DISCUSSION}

3.1 Implementation of Hindu Religious Education Curriculum in Pasraman Rsi Markandya Taro

\subsubsection{Widya Pasraman Primary Curriculum}

The implementation of Hindu religious education curriculum in Pasraman Rsi Markandya Taro refers to the curriculum of Hindu religious education units which are formal pasraman institutions. The first thing to note, when the educator component of Pasraman Markandya Taro implements the Widya Pasraman Primary curriculum is related to Graduates Competency Standards (hereinafter written SKL). SKL that has been formulated for the Widya Pasraman Primary School education unit level, and in Pasraman Markandya Taro is used to formulate the basic competencies needed to achieve them. Considering to the competency standard of graduates that must still be achieved at the end of the Widya Pasraman 
Primary School level, which lasts 1-2 years, in an effort to facilitate the operational formulation of basic competencies, it is necessary to have an objective between stating the achievement of competencies at the end of the class level at the Widya Pasraman Primary level.

Core Competencies (KI) for Widya Pratama Primary Level Widya Pasraman Primary School Competencies. In this case, Pasraman Rsi Markandya Taro also determines KI learning based on the notation of several KI which includes KI-1 to KI-4 in which placing spiritual attitude as the main thing. Hindu religious education should be able to foster spiritual attitudes of students, such as the mandate of the Vedas (Atmadja, 2002). In the National Education System Law No. 20 of 2003 which states that competencies consist of attitudes, knowledge and skills competencies.

The implementation of the Hindu religious education curriculum in Pasraman Rsi Markandya Taro is based on number of basic competency standards such as competence on spiritual, social, knowledge and skills aspects. All aspects are considered in the application of learning, so students can have holistic intelligence, and not only cognitive intelligence, but also social attitudes and skills.

Students in Pasraman Rsi Markandya Taro are not given a burden of learning that is not in accordance with SKL, KI and KD. Still in this context the burden of learning refers to aspects of attitude, knowledge and skills, that effective and efficient learning is when educators can explore the potential of students, so that it is reflected in the attitude of behavior, knowledge and skills or skills possessed later, when it has graduated (Atmadja , 2002).

WidyaPasraman Primary Curriculum uses the thematic integrative learning approach. Learning in Pasraman Rsi Markandya Taro, the curriculum contains local content related to character education, arts and culture. Learning approach with art and culture will foster cultural attitudes and students are embedded in attitudes to love their own culture amid the onslaught of new cultural currents (Endraswara, 2010). The task of educators in this case applies the curriculum with an integrative thematic approach. Whatever learning is obtained by pasraman students, it should be integrated with morality education as a foundation for character education. Bhagawan Sri Satya Sai Baba in his Summer Discourse stated that spiritual knowledge is a material knowledge base (Kasturi, 2008). Thus, in fact Hindu religious education can be used as an educational model based on good character development.

The curriculum structure of Primary Widya Pasraman (TK) Ages 46 Years, Development of Core Competencies to Basic Competencies in Pasraman Rsi Markandya Taro refers to the formal pasraman curriculum. It can be observed that there are number of KI and $\mathrm{KD}$ in supporting learning in an effort to develop several notations, such as spiritual, social attitude, knowledge and skills. The depth of curriculum content in each subject in each education unit is outlined in competencies that must be mastered by students according to the learning burden (Poerwati, 2013). Pratama Widya Pasraman is the initial level of learning, the learning burden of students in Pasraman Rsi Markandya Taro is as described in KI1-KI3 which is then supported through KD in the curriculum.

\subsubsection{Adi Widya Pasraman Curriculum}

Implementation of Adi Widya Pasraman curriculum in Pasraman Rsi Markandya Taro. Graduates 
Competency Standards (SKL) which have been formulated for elementary school level education units/Adi Widya Pasraman are used to formulate the basic competencies needed to achieve them. In applying Adi Widya Pasraman curriculum in the Pasraman Rsi Markandya Taro, it still refers to KI and $\mathrm{KD}$ as the curriculum education unit at Pratama Widya Pasraman. This is considered important, because the application of Adi Widya Pasraman curriculum should be continuous and coherent with previous learning. The curriculum of the primary education unit or elementary school must be able to describe the appearance of an ability which in general must be mastered by graduates (Jones, 2008). In this context, at least students of Pasraman Rsi Markandya Taro have the basic ability to support the achievement of graduate competencies in national education standards.

The learning load applied by teacher of Pasraman Rsi Markandya Taro refers to the learning load expressed in class hours per week for one semester. Learning load in elementary/AWP classes I, II, and III are $30,32,34$ hours per week. The learning load in elementary/AWP grades IV, V, and VI is 36 lessons per week. The duration of one hour elementary school/MI is 35 minutes.

The SD/AWP curriculum implemented by Rsi Markandya Taro pasraman education component uses an integrative thematic learning approach from class I to class VI. The implementation of Adi Widya Pasraman's curriculum in Pasraman Rsi Markandya Taro is based on a number of $\mathrm{KI}$ and $\mathrm{KD}$ that refer to the translation of the formal institution pasraman curriculum. The KI and KD are applied based on measured and systematic leveling based on the level of the education unit. The application of curriculum in Adi Widya Pasraman in
Pasraman Rsi Markandya Taro still puts the effective domain as important because Hindu religious education is a learning process that can direct students to develop attitudes and behaviors that have character. Only then will cognition and psychomotor dominance, as Bloom's taxonomy, be explained in the pedagogical domain. This is certainly in line with national education standards set in the legislation, such as what is contained in the National Education System Law No. 20 of 2003 which states that the purpose of education is to create human resources who have attitudes and behaviors that believe in God, are spiritually and physically intelligent and responsible.

\subsubsection{Madyama Widya Pasraman curriculum}

The application of the Madyama Widya Pasraman curriculum in the Pasraman Rsi Markandya Taro also refers to the Graduate Competency Standards (SKL) which have been formulated for the level of the Middle School / Madyama Widya Pasraman (MWP) education units. The SKL that is used to formulate the basic competencies needed to achieve it is very important.

Junior High School Competencies/Madyama Widya Pasraman (MWP) in supporting Core Competencies, learning outcomes of subjects are broken down into basic competencies. The determination of KI and $\mathrm{KD}$ in the Madyama Widya Pasraman curriculum still counts 4 notations as the standard for formal Hindu religious education in the curriculum. KI is the development of spiritual attitudes, social, knowledge, and skills.

The burden of learning in SMP/MWP for classes VII, VIII, and IX each of 47 hours per week. The duration of one study hour for SMP/MWP is 40 minutes. One semester consists of 18 
weeks. The implementation of the curriculum at the Rsi Markandya Taro Pasraman educational institution has fulfilled the national standard of education which is organized in a planned, directed and continuous manner. In addition, the domain of teaching that emphasizes the principle of Bloom's taxonomy is still enforced by paying attention to several things, such as the effective domain that deals with attitudes, values and appreciation.

\subsection{Constraints Faced in the Implementation of the Hindu Religious Education Curriculum in Pasraman Rsi Markandya Taro}

\subsubsection{Human Resources (HR)}

From the technical aspect of the implementation of Hindu religious education curriculum that refers to the 2013 curriculum, there are still number of things that cannot be reached optimally by pasraman include developing curriculum devices in schools such as lesson plans and syllabus, assessment systems, readiness of human resources (HR), facilities and infrastructure/supporting facilities as well as teacher and student readiness in the process of forming student behavior. This is due to limited understanding as a result of the swift flow of changes in the application of the curriculum and it is clear that there are things that cannot be understood or reached maximumly.

Teachers as one of the educational communities that are directly contact with the curriculum are often confused by the policy of changing the curriculum often, especially in formal pasraman schools that are still classified as new schools. Every teacher must meet the requirements as human beings who are responsible in the education field(Suhanan, 2014).

This shows that teacher performance has not beenyet fully supported by adequate degrees of competency mastery, therefore a comprehensive effort is needed to improve teacher competency. Many teachers do not understand well about the curriculum, so there are some among teachers especially Hindu religion teachers who do not understand about the preparation of the Learning Implementation Plan (RPP), and appropriate learning media used in accordance with student psychology. There are still teachers who do not understand the 4 core competencies, this is due to the lack of training, experience, and knowledge they have (Interview, Madriana 2019).

The lack of teacher's ability in making Learning Implementation Plans (RPP) becomes a particular obstacle for some teachers, whereas if it is viewed from the curriculum aspect that it expects teachers to be able to prepare RPP independently so that each school has its own characteristics that are in line with the vision and mission of Pasraman but still refers to the applicable national provisions.

In the application of Hindu religious education curriculum which is oriented towards student activities, the quality of teachers can be viewed from two aspects, namely in terms of process and in terms of results. In terms of the process, the teacher is said to be successful if able to involve most of studentsactively, both physically, mentally and socially in the learning process. In addition, the quality of the teacher can also be seen from the passion, enthusiasm of teaching and the presence of self-confidence. Based on the description above, it can be seen that the obstacles in the implementation of the Hindu religious education curriculum lie in the conditions, human resources (HR), and students (input). Development and training with learning models consist of training preparation strategies, learning and training processes, as well as training evaluation stages, but their application has not 
reached $100 \%$, although at the training and learning process stages have been carried out in accordance with the predetermined training planning and preparation strategies (Hamsinah , 2016). This condition mandates that the relevant agencies appear to have not been able to optimally disseminate information about the curriculum in the implementation of formal pasraman schools, so that at the level of the field there is confusion on the part of the education providers themselves. So far, HR and in this case teachers as educators have become the most important obstacle faced by educationworld in applying the 2013 curriculum. Many HR people are not ready to implement the curriculum, so there is no learning transformation that leads to the achievement of national education goals set in the Law National Education System.

\subsubsection{Time Allocation}

The application of the Pasraman curriculum commonly in Pasraman Rsi Markandya Taro is still not maximum, because the number of hours of face-toface subjects exceeds 42 hours. If added to general subjects so that students will lack learning time, whereas the current pasraman curriculum is more aimed at pasramanbording school(Interview, Wiranata 2019). By limited time allocation, teachers are expected to achieve the completeness of basic competencies in the subject matter, for that pasraman teachers try as much as possible to streamline the allocation of time available and pursue the remaining subject matter so that cognitive and affective aspects in the learning process become invisible. In the learning process, the teachers try to put forward psychomotoraspects,students as support in terms of assessment criteria in addition to cognitive and affective aspects.
The implementation of Hindu religious education learning programs as an application of the content of the pasraman curriculum often cannot be achieved properly given the government policy which requires a public repetition, has not collided with school holidays both public and special holidays make teachers seem to pursue the target so that the material runs out quickly even though on the one hand the teacher faces different student backgrounds with academic abilities that are not the same obstacles as the implementation of the curriculum in Pasraman Rsi Markandya Taro.

\subsubsection{Financing}

The financing factor is an important factor in implementing a program. Without the cost of the program it will not be able to run smoothly and continuously. In this religious education curriculum, the cost factor is indispensable especially with regard to assessments that refer to the 2013 curriculum. Inefficient resource mobility, due to high costs (Ghafur, 2017).

Assessment in the 2013 curriculum will not be able to run properly if there is no costs allocated to teachers to copy the assessment instruments. With so many assessment instruments certainly require a lot of costs. With very minimal welfare, absolutely teachers will find it hard to pay their own costs (Interview, Sucitra 2019).

From the results of interviews with informants, it can be concluded that the cost factor is a supporting success factor of Hindu religious education curriculum, this is due to the large number of assessment instruments so that it has implications for the cost of photocopying instruments especially on self-assessment and peer-to-peer assessments. In the 2013 curriculum it has actually been mentioned that the 
standard education costs consist of investment costs, operating costs, and personal costs. The education unit investment costs include the cost of providing facilities and infrastructure, human resource development, and permanent working capital. Personal costs include education costs that must be spent by students to be able to follow the learning process in an orderly and continuous manner. While the operational costs of education units include: salaries of educators and education personnel as well as all benefits and those related to the welfare of educators and education personnel. Based on this, the actual management of education costs can be done refers to the education funding standards that have been set in the education unit.

\subsubsection{Facilities and infrastructure}

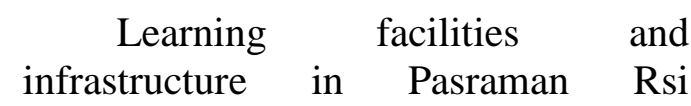
Markandya Taro and their learning facilities are still inadequate. In this case the practical pasraman education teachers, especially Hindu religious teachers do not have yet a teacher handbook that can be used as a reference in the learning process. Learning facilities and infrastructure standards in schools are required to meet a number of standards set by the government, it is caused by the existence of learning facilities and infrastructure as a benchmark from the government about the appropriateness of the schools being organized (Tanu, 2010). Implementation of the Hindu religious education curriculum in Pasraman Rsi Markandya Taro, obstacles that arise include the following: (1) student books and teacher books are not availableyet, (2) students do not have specific practice spaces, (3) Hindu learning media that are owned by schools is very limited, (4) the development of learning facilities has not been carried out optimally (Interview, Sukerta 2019).
Based on this explanation in relation to the implementation of the Hindu religious education curriculum in Pasraman Rsi Markandya Taro, facilities and infrastructure are indeed very necessary especially teacher and student books which are the main weapons needed by teachers in the learning process should be available earlier before the school year begins, but in the reality is that teacher and student books are not availableyet, this is the main obstacle in the implementation of the Hindu religious education curriculum, particularly in the standard of facilities and infrastructure, besides the lack of instructional media that are needed by teachers. Management of facilities and infrastructure must be emphasized even more in educational institutions such as the school (Megasari, 2014). Each education unit is actually required to have facilities and infrastructure that includes furniture, educational equipment, educational media, books and other learning resources, consumable materials, and other equipment needed to support an orderly and sustainable learning process. This is sometimes becomes an obstacle in learning, namely the provision of learning facilities and infrastructures in accordance with the standards of facilities and infrastructure in national education.

3.3 Efforts are made to overcome the obstacles encountered in the Application of the Hindu Religious Curriculum in Pasraman Rsi Markandya Taro

\subsubsection{Provide Training for Teachers}

The presence of teachers is the culmination of the educational process. If a teacher does not understand the meaning of the curriculum in an integrated manner then it will make a bad contribution to the educational process. Indeed, it is time for the government to look down or backward 
about the competence of teachers. The predicate of teacher is not only limited to seeking incomelike other jobs. Because teachers are icons that give birth to the nation's future generations (Interview, Jayanti 2019).

Based on the informant's statement above, the government is expected to pay more attention to teachers especially in increasing teacher professionalism by givingmore training such as workshops, seminars, upgrading for Hindu religious teachers especially in the application of new curriculum, namely the Hindu religious education curriculum. The spearhead of curriculum implementation is in the implementation of the tasks and responsibilities of teachers (Interview, Emayani 2019). Government policies that provide professional allowances for professional teachers require teachers to work professionally as well. Thus that teachers who understand the curriculum well, have clear vision of what to do in relation to their duties as a teacher. Using human resources who have good behavior is the first strategy in improving pasraman quality.

Policy in providing opportunities and challenges for teachers to further update their learning in accordance with the demands of development. Thought to develop and refresh learning models of proper religious education is very urgent. Given one of the criteria for curriculum content or material above, that the contents of a curriculum must be in accordance with the interests of students, it does not rule out the possibility that the curriculum can be developed in accordance with the interests of students.

If the contents of the Hindu religious education curriculum are arranged in accordance with the times and are packaged as attractive as possible, then the interest of students to learn them will be even greater. Teachers must try to improve their quality or develop themselves more so they can become role models for their students. So that they can produce highquality, good character, competitive and religious students (Interview, Weni 2019).

Based on the statement of the informant above, it can be explained that, to increase students' interest in learning Hinduism, beside developed the structure of curriculum content in accordance with the needs of the times, it can also be realized through increasing teacher competence.

\subsubsection{Develop a Learning Program}

To bring forth the quality of Hindu religious education with vision in the future, a superior learning program is needed and is able to make teachers and students enjoy the material with fun. The process of designing a learning program usually begins before the teaching and learning process (PBM) takes place. This activity is designed by leaders, teachers and involves drafter and community in order to meet the needs of stakeholders. Excellent learning programs are part of the curriculum's principles, strategies and objectives. The superior program is intended so that the educational institution has competitiveness as well as community attraction, in addition to the needs of educational institutions so that the learning process of Hindu religious education can take place optimally. Assessment of the implementation of the learning program seeks to assess how high the level of learningquality carried out by the teacher (Widoyoko Tayibnapis, 2000). Therefore, decision makers at the education unit level must review whether still problems and barriers to learning so far, especially regarding the application of the Hindu religious education curriculum.

Through superior learning, the implementation of Hindu religious 
education will be seen as a plus (added) in order to give birth to an adequate output, giving birth the strong individual spiritual character, sradha and bhaktithat has been increased. High science and skills if it's not balanced with a strong understanding of religion, will slip on actions easily that violate the teachings of dharma. With the right teaching approach, understanding and appreciation of Hindu values will become the frame of view for each student in their daily lives wherever they are (Interview, Madriana 2019). Recognizing the importance of the Hindu religious education curriculum based on this statement, it is necessary to simplify the subject matter and complement it with models and learning strategies that are more relevant to social change situations. Learning resources are not only limited to the equipment and materials used in the teaching and learning process (Arsyad, 2017).

\subsubsection{Utilizing Effective Learning Resources}

Learning resources are something that supports teaching and learning activities, both within school environment and outside the school environment. Learning resources are things that can contain messages to be presented through the use of tools or by themselves can also be something that is used to convey messages stored in learning material that will be given (Hafid, 2011). Students are given space to develop student potential. Through sacred buildings such asPadmasana in the school is not only as a place of prayer, Padmasana school can also use as function to implement of spiritual knowledge as mentioned in the 2013 curriculum, so that students who are not academically intelligent also have spiritual intelligence.
As an effort to implement the 2013 curriculum, specifically the application of core competency (KI) 1 , which is a spiritual attitude, in schools in daily life students are advised to make offerings in class through tri sandhya and routinely before entering the class as soon as new students come from home students go directly to the padmasana school to offer prayers (ngaturang bhakti) by means of canang and incense (Interview, Sukerta 2019).

Based on the explanation of the informant above, that pasraman students are always in their daily lives formed by sradha and bhakti through prayer routines at padmasana school. That learning resources can be taken from the environment in human form or in the form of objects around it such as one of the schools that is actually a real and contextual Hindu religious education material. It is time for the teacher to begin to understand that the teacher is not the only source of learning. The teacher is one source of learning for students. For this reason, the teacher motivates students to want learning, as well as in the implementation of the Hindu religious education curriculum must be changed from a doctrinal mindset towards more awareness.

The Hindu religious education curriculum really requires such learning resources to train the sensitivity of reasoning power, sensitivity of the soul and heart to grow in their appreciation and practice. Functionally the source of learning outside the school is to perfect the learning activities of Hindu religious education in order to make it really have a deep and lasting impression on students. Education contextuallymust be able to meet the needs in accordance with the demands of the times that is preparing a generation who is ready to live and live in his day, both in an effort to equip his abilities and life skills (Herlambang, 2018). 
With the progress of information and technology today, in addition to the learning resources mentioned above, the internet is also used as a source of learning for students both at school and outside of school. Assignments given by teachers in schools that cannot be understood by students and parents of students, can be searched on the internet. Because everything can be found on the internet. From this description, it can be said that the creation of learning resources was chosen based on the substantial content of the curriculum to be realized.

\section{CONCLUSION}

The administration of education absolutely get constraints both internal and external constraints. These constraints must certainly be sought for solutions to obtain educational results that are in accordance with the mandate of the Act, and have implications for related aspects. The curriculum as an educational substance needs to be decentralized, especially in the development of syllabus and its implementation which is adjusted to the demands of the students' needs, the state of the school, and the condition of the school or region.

The curriculum was developed as a guide in organizing learning activities to achieve certain educational goals. The implementation of the Hindu religious education curriculum that refers to the 2013 national curriculum has not been running optimally and there are still many constraints that need to be reviewed and accelerated the preparation of facilities and infrastructure. Constraints faced in the implementation of Hindu religious education curriculum at the level of Primary Widya Pasraman, Adi Widya Pasraman and Madyama Widya Pasraman in Pasraman Rsi Markandya Taro are on average the same, namely (1) Human resources (HR), (2) Time allocation (HR) 3) Funding and (4) Facilities and infrastructure. The efforts made to overcome the obstacles encountered in the application of the Hindu religious education curriculum in Pasraman Rsi Markandya Taro are: (1) Providing training for teachers, (2) Arranging learning programs, and (3) utilizing learning resources that are effective.

\section{REFERENCES}

Arsyad, A. (2017). Media Pembelajaran. Jakarta: Rajawali Pers.

Atmadja, N. B. (2002). Filsafat Ilmu Dari Pohon Pengetahuan Sampai Karakter Keilmuan Ilmu Pendidikan-Hukum. Denpasar: Pustaka Larasan.

Endraswara, S. (2010). Teori Kritik Pendidikan Sastra. Yogyakarta: Narasi Wacana.

Ghafur, H. S. (2017). Arsitektur Mutu Pendidikan Indonesia. Jakarta: Bumi Aksara.

Hafid, H. ab. (2011). Sumber dan Media Pembelajaran. Jurnal Sulesana.

Hamsinah, H. (2016). Pegembangan Sumber Daya Manusia Bagi Tenaga Guru. SOSIO-DIDAKTIKA: Social Science Education Journal. https://doi.org/10.15408/sd.v3i1.3799

Herlambang, Y. T. (2018). Pedagogik (Telaah Kritis Ilmu Pendidikan dalam Multiperpektif). Jakarta: Bumi Aksara.

Jones, W. (2008). Sejarah Munculnya Kurikulum (Terjemahan Buku The Elementary of Curicculum). Jakarta: Pustaka Gramedia ada dalam kepustakaan IKAPI.

Kasturi, N. (2008). Wacana Musim Panas; Uraian Wacana Bhagawan Sri Sathya Sai Baba. Jakarta: Yayasan Sathya Sai Books Trust.

Megasari, R. (2014). Peningkatan Pengelolaan Sarana dan Prasarana Pendidikan untuk Meningkatkan Kualitas Pembelajaran di SMPN 5 Bukittinggi. Administrasi Pendidikan.

Poerwati, E. (2013). Teori, Konsep dan Pengaplikasiannya Dalam Pembelajaran. Bandung: Renika Cipta.

Sandika, I. K. (2011). Pendidikan Menurut Weda Bidang Spiritual Bagi Generasi Muda. Denpasar: Pustaka Bali Post.

Suhanan, C. (2014). Konsep Strategi Pembelajaran. Jakarta: PT Refika Aditama. 
Tanu, I. K. (2010). Konsep dan Makna Pembelajaran di Era Biobal. Denpasar: Sari Khyangan Indonesia.

Widoyoko Tayibnapis, F. Y. (2000). Evaluasi Program Pembelajaran. Jurnal Ilmu Pendidikan. 